\title{
The Effect of the Marketing Mix on Customer Purchase Decision in the Mobile Telecommunication Industry in Sub-Sahara Africa
}

\author{
Emmanuel Selase Asamoah \\ University of Professional Studies
}

This study determined the awareness of the marketing strategies of the mobile telecommunication companies; customers' purchase decision of products and services provided by the mobile telecommunication companies, and finally the influence of customer awareness of marketing strategies on customer purchase decision. The study adopted a quantitative approach with 300 respondents. The study found that customers of the various mobile telecommunication companies had knowledge of the 7Ps marketing strategies of the mobile service providers. Furthermore, respondent's intentions to patronize the services of their mobile networks were about the same for all customers. The study also found that customer awareness of the pricing strategy $(r=.146, p=.011)$, product/service strategy $(r=.120, p=.038)$, process strategy $(r=.153, p=.008)$, and promotional strategies $(r=.129, p=.025)$ all have significant positive correlation on customer intention to patronize the services of the telecommunication companies. However, customer awareness of the marketing strategy (marketing mix) played no significant role in predicting the decision of the customer to patronize the services of their mobile telecommunication companies.

Keywords: marketing mix, consumer behaviour, customer purchasing decision, marketing strategies, mobile telecommunication

\section{INTRODUCTION}

Over the last two decades, there has been an increase in the intensity of competition in global markets. Consequently, organizations are prompted to ensure that they satisfy the needs and wants of their customers in a more efficient and effective manner than their competitors (Kotler, 2010). The trends in global competition have also affected the mobile telecommunication industry in many countries. The nature of competition in the mobile telecommunication industry has led to the development and use of various marketing strategies aimed at influencing consumer purchase decision (Schiffman \& Kanuk, 2007). In Ghana for instance, the various network operators are competing for the limited number of mobile phone users. However, customers are usually selective in their choice of alternative expenditure. In view of that, mobile telecommunication companies are expected to have strategic marketing plans that can awaken and increase customer demand for the organization's products and services (Palmer, 2001).

According to Clancy and Kriegafsd (2000), in order for companies to develop a viable, cost-efficient strategy for marketing its products and services, it is essential that they have a comprehensive understanding of their own business and the markets. Generally, marketing strategy has to do with the adaption and interaction of marketing mix elements within the environment (Singh, 2012; Latif, Abideen, 2011). Therefore, the purpose of marketing strategy is to define the nature, strength, direction, and interface 
between the elements of the marketing mix and the variables within the firm's environment at a particular time (Blumberg, Cooper \& Schindler, 2005). Researchers such as Levie (2006) and Brassington and Pettitt (2001) have explained that organizations develop with the aim of establishing, building, defending and maintaining its competitive advantage. In the end, such strategies influence consumer purchase decision. Therefore, there is a need to blend the elements of the marketing mix to develop a formidable marketing strategy for the company's competitive advantage (Brassington \& Pettitt, 2001).

Due to the intense rivalry among the companies in the telecommunication sector, there has been a number of marketing strategies aimed at promoting their products and services. Promotional campaigns such as sales tactics, telemarketing, direct mail, personal selling, advertisements in the traditional media and new media channels and sales promotions have been implemented to ensure the companies competitiveness over time (Peng \& Wang, 2006). The essence of these strategies is to influence customer buying behavior. However, whether or not the various marketing strategies actually influence consumer purchase decision is quite controversial among marketing researchers. This research provides a better insight into how the various components of the marketing mix can be used in the development of marketing strategies for implementation by mobile telecommunication companies in Ghana to influence customer purchase decision. This will provide information about the extent of customer awareness and the influence of the marketing strategies in the telecommunication companies. In the end it is expected that the findings would help managers of the mobile telecommunication companies to fashion out better strategies in realizing their objectives of competitiveness, profitability and customer loyalty.

\section{MARKETING STRATEGY AND CONSUMER BEHAVIOR}

For any marketing strategy to give the desired outcome, it must have an impact on customer behavior in a favorable manner. A study by Ala'Eddin, Abdullah, Dalia and Najla (2013) sought to analyze the effect of marketing strategy on patient satisfaction in the health sector. The study used the variables within the marketing mix as independent variables whiles the dependent variable was patient's satisfaction. The independent variables that were used were health service, pricing, distribution, promotion, physical evidence, process, and personal strategies. It was revealed from the study that health service, promotion, physical evidence, process and personal strategies had a significant effect whiles pricing and distribution strategies did not have a significant effect. Furthermore, a study conducted by Subramanyam and Venkateswarlu (2012) on the types of marketing strategies implemented by marketers to gain the attention and cognition of both existing and potential customers as well as the role these marketing strategies play in the customer buying process showed that the income levels of buyers, intensity of advertising and the customers level of education primarily determine their decision to own a mobile phone handset.

In another study by Obasan and Soyebo (2012) that sought to examine how effective promotion affects customer buying decisions revealed that promotion as a marketing mix variable has a significant effect on marketing management. The implication of this finding is that, the efficacy of promotion tool is in the fact that the survival, sustenance and expansion of business in the telecommunication industry depends on the intensity of promotion. Consequently companies in the industry will have to review their marketing strategy regularly in order to satisfy the needs of customers (Chaniotakis, Lymperopoulos and Soureli, 2010). Adock, Halborg and Ross (2001), agrees that even a purchase decision can be affected by unanticipated situational factors. Some of these factors could be directly associated with the purchase. For instance, the outlet (place) where the purchase is to be made, the quantity to be bought, when and how to pay contribute to the buying decisions of consumers. Very often the traders or suppliers remove the need to make this decision by either including the essentials in the form sales promotion tools such as coupons, deals, rebates and samples. The timing decisions are usually connected with the payment decision and the acceptance of credit cards has to a large extent reduced the importance of these decisions for many purchasers (Wang, Wang, Gaskin and Wang, 2015). Sales promotion provides customers with samples of the products for them to test as well as provide customers with the most needed information concerning the product (Chaudhuri and Ligas, 2009). 
Studies have shown that in the consumer decision process, at the recognition stage and the information search stage, the sales promotion tool that is more applicable is the giving of free samples (Sashi, 2012; Bilal, Al Mqbali, 2015; Festa, Cuomo, Metallo, Festa, 2016). This is because the risk of buying a new product is high so if customers are able to get free samples for trial, they are able to reduce the risk that comes with buying new product with less reputation. When customers are provided with relevant information, they get the opportunity to try the product and services; get to know whether it satisfies their needs and also enjoy a price reduction (Asamoah, 2014). The variables in the marketing mix can serve as a strategic tool and can be used to draw customers to the product (Chaniotakis, Lymperopoulos and Soureli, 2010). Due to the strength of the sales promotion tool, it also makes customers to buy on impulse (Asamoah, 2021).

\section{MARKETING MIX - THE BASIS FOR DEVELOPING A COMPETITIVE MARKETING STRATEGY}

Marketers use a number of tools to elicit the desired responses from their target markets. These tools can be seen in the elements of the marketing mix. The marketing mix is a set of marketing tools that companies use to pursue their marketing objectives in the target market (Beckett, 2000). The decision regarding the use of the marketing mix must be made to influence the trade channels as well as the final consumers. Typically, companies can change their price, sales-force size, and advertising expenditures in the short run (Kotler \& Keller, 2009). However, they can develop new products and modify their distribution channels only in the long run (Blackwell, Miniard \& Engel, 2006). Thus, the company typically makes fewer period-to-period marketing-mix changes in the short run (Asamoah, 2021). The marketing mix is a model for creating and implementing marketing strategies. It stresses the blending of various factors in such a way that both organizational and consumer objectives are attained.

In the view of Kotler (2001) marketing mix is every important because it is the wheel around which all the marketing strategies revolve. Kotler (2001) explains that "The marketing mix represent the sellers view of the marketing tools available for influencing buyers, and each marketing tool is designed to deliver a customer benefit." Kotler (2001) further explains that a company which seeks to obtain favourable response and become competitive in the market should be able to meet customer needs economically, conveniently and with effective communication; and the buying behaviour of consumer's are largely influenced by cultural, social, personal and psychological factors. According to Blackwel, Minniard and Engel (2001) marketing mix serves as an analytical tool, which tends to guide enterprises when taking decisions on the strategic direction in the markets they operate. Furthermore, Blackwel, Minniard and Engel (2001) indicate that the marketing mix can be adjusted frequently to meet the changing needs of the market segments of interest, and the other dynamics that prevails in the marketing environment (Barlon, 2006). The elements of the marketing mix used in this study are product, price, place, promotion, people, process and physical evidence.

\section{Product Decisions}

The term "product" generally refers to tangible, physical products. Although this typically refers to a physical product, it has been expanded to include services that are provided by a service organization. The specification of the product is one of the elements that a marketer has at their control. For example, the product can include certain colors, scents, and features. In the broad sense when a consumer purchases a product it also includes the post-sales relationship with the company. The post-sales relationship can include customer service and any warranty (McCarthy, 1999).

\section{Price Decisions}

The price is the amount paid for a product or service. Often, especially in business-to-business marketing, this can also include the Total Cost of Ownership (TCO). Total cost of ownership may include costs such as installation and other products required to deliver a complete functional solution (McCarthy, 1999).The most obvious benefit of discounts is that it influences the customer in the buying-process at the 
point of purchase. Also, for customers who are price conscious, lower prices tends to influence their buying decision (Asamoah, 2021). The price drop is likely to catch the attention of the customer especially for products or services that they do not buy regularly (Festa, Cuomo, Metallo and Festa, 2016). According to Inman, McAlister and Hoyer (1998) customers are more prone to purchase a product with a lowered price. The use of promotion signals such as sign, marker or other display of value addition appeal to customers.

\section{Place (Distribution) Decisions}

Place represents the location where a product or service can be purchased. It is often referred to as the distribution channel. It can include any physical store as well as virtual stores. Distribution is about getting the products to the customer (McCarthy, 1999; Szopa and Pękała, 2012). The proximity or otherwise of a particular distribution outlet tends to affect consumer purchasing behavior. Hence there is a need for companies to leverage on the most effective distribution channels to get their goods and services available to consumers at the right time.

\section{Promotion Decisions}

Within the marketing mix framework, promotion has to do with the various aspects of marketing communication. That is, the communication of information about the product or service with the goal of generating a positive customer response. Promotion represents all of the communications that a marketer may insert into the marketplace. It includes information deployed through channels such as TV, radio, and print advertising, as well as coupons, direct mail, billboards, and online advertising. Although quite underestimated, human sales force constitute an important aspect of the promotion strategy. Studies have shown that customers may rather buy a product or patronize a service only when it is sold or presented to them by a known salesperson. In this case, the service, perceived or real can be defined as a feature of the product (McCarthy, 1999).

\section{People/ Participants Decision}

The human factor plays a critical role in service organizations, especially during the service delivery process when the employees have interactions with customers. Service marketing has long stressed the importance of customer contact as crucial components in delivering a high quality service and contributing to overall customer satisfaction (Booms \& Bitner, 1981). The telecommunication service is one field where employees are considered to be of particular importance. It is widely argued that the overall quality of the delivered service for organizations such as health services is influenced, among other things, by the nature of the relationship between the customer and employees of the service providers (Blumberg, Cooper, \& Schindler, 2005). Customer relationships tend to differ considerably with respect to content, frequency, duration, and regularity (Chaudhuri and Ligas, 2009).

\section{Process Strategy/ Service Delivery}

Process is one of the crucial elements of the expanded marketing mix components in services that should be a distinct strategic element. This is because the process may influence the initial customer decision to purchase a service and affect the level of customer satisfaction (Festa, Cuomo, Metallo and Festa, 2016). Zeithaml and Bitner (2000) found in their study that the top management challenges across the service sector are maintaining quality of service, hiring employees, and employee training. The process aspect the marketing mix has three major components, which are the flow of activities (standardized or customized), the number of steps (simple or complex) and customer involvement. The process of service delivery can be thought of as the expressive performance of a service. Its descriptors are as follows: duration, work-area appearance, employee appearance, empathy, assurance and employee effort, reliability and customer participation (Grönroos, 2000).

\section{Physical Evidence Strategy}

The appearance of a work area is similar to physical appearance, identified previously as a structural descriptor (Jones, 2003). Work area appearance includes such things as cleanliness and tidiness or the 
general appearance of the service location on a day-to-day basis. Some items like furniture, wall coverings, or pictures could be designed into the service environment. Some services marketing researchers (Lovelock, 2001; Palmer, 2001) have pointed out the importance of physical evidence for sending a consistent message and retaining a coherent image about services-based organizations. Palmer (2001) has focused on the vital role of providing tangibles as a significant component of the company service offer. Lovelock (2001) has said that physical evidence is one of the important elements of the marketing mix of services management paradigm by which the company can provide tangible objects to customers during the service delivery process. Furthermore, such tangible metaphors are used in such communications as advertising, symbols, and trademarks (Lovelock, 2001).

\section{OBJECTIVES OF THE STUDY}

The following are the objectives that were formulated for the study:

a. To determine customer awareness of the marketing strategies (marketing mix) in the mobile telecommunication industry in Ghana

b. To examine customer purchase decision of products and services in the mobile telecommunication industry using the marketing mix elements.

c. To evaluate the effect of customer awareness of marketing strategies (marketing mix) on customer purchase decision in the mobile telecommunication industry.

\section{METHODOLOGY}

This study adopted the survey research design. The study is also descriptive, explanatory and crosssectional with the sole purpose of determining the effect of marketing strategies on customer purchase decision in the mobile telecommunication industry in Ghana. It is descriptive because it seeks to describe the marketing tools often encountered by customers in the mobile telecommunication industry, and the purchase decision of customers. Furthermore, the study is explanatory because it sought to evaluate the effect of marketing strategies on customer's purchase decision. Again, the study is cross-sectional because it focuses on a particular phenomenon (marketing strategy and customer purchase decision) at a specific period of time as opposed to longitudinal research which focuses on the phenomenons' successive time interval (Saunders, Lewis and Thornhill, 2009). The study used a structured-questionnaire as the primary data collection instrument. Only customers of the various mobile telecommunication services providers were sampled. A total of 300 customers were conveniently sampled.

\section{RESULT AND DISCUSSION}

The following are the results of the data analysis from the survey. The results are presented with descriptive and inferential statistics.

\section{Demographic Factors}

The following are the demographic characteristics of the respondents who were customers and users of the various Mobile Service providers. There were 300 participants for the study. A total of $52.7 \%(\mathrm{n}=158)$ of the participants were females and the remaining $47.3 \%(n=142)$ represent male respondents. Regarding the age of the sampled respondents, majority, $57 \%(\mathrm{n}=171)$ were within the age group of $15-24$ years. This was followed by those who were 25-34 years of age. This group constituted $32.3 \%(n=97)$ of the total valid respondents. While $8.0 \%(n=24)$ of the sampled customers were $35-44$ years of age, $2.3 \%(n=7)$ respondents were found to be $45-54$ years, and $0.3 \%(n=1)$ was found to be 55 years and above.

\section{Level of Usage or Patronage of the Most Preferred Network}

Regarding the level of patronage of most preferred networks by the sampled customers as shown in Table 1, large majority, 87.4\% $(\mathrm{n}=262)$ claimed they use the network for both calls and internet services. 
While $7.3 \%(n=22)$ use their preferred network for calls only, the remaining, 5.3\% $(n=16)$ claimed they use their preferred network for internet services only. This means that the use of mobile telecommunication services for both calls and internet services dominate customer usage.

TABLE 1

LEVEL OF USAGE OR PATRONAGE OF THE MOST PREFERRED NETWORK

\begin{tabular}{|l|l|l|}
\hline Category & Number & $\%$ \\
\hline Calls only & 22 & 7.3 \\
\hline Internet services only & 16 & 5.3 \\
\hline Both calls and internet services & 262 & 87.4 \\
\hline Total & 300 & 100.0 \\
\hline
\end{tabular}

Source: Authors calculation

The implication is that the most of the customers are regular users of their networks and therefore had some knowledge about the marketing strategies of the networks that influence their intentions to patronize the service of the networks.

\section{Customer Awareness of the Marketing Strategies (Marketing Mix) of Companies in the Mobile Telecommunication Industry}

The first objective of the study was to determine customer awareness of the marketing strategies in the mobile telecommunication industry in Ghana. The 7P marketing strategy model was adopted to achieve this objective and the responses were given on a Five-point Likert Scale. Mean and standard deviation were used to present the findings. If the overall mean value significantly greater than 3.0 (Test value) then the customers agreed that they have knowledge of the marketing strategies as implemented by the mobile telecommunication companies. One-sample z-test was performed at 5\% alpha to determine whether or not the mean value are greater than 3.0 using the hypothesis $(\mathrm{Ho}: \mu \leq 3.0 ; \mathrm{H} 1: \mu>3.0)$. The results are summarized in table 2 below.

TABLE 2

\section{CUSTOMERS' AWARENESS OF THE 7P MARKETING STRATEGIES OF MOBILE TELECOMMUNICATION COMPANIES}

\begin{tabular}{|l|l|l|l|l|l|l|}
\hline & Mean & St. dev & z-stat & $\begin{array}{l}\text { Sig. (one - } \\
\text { tailed test) }\end{array}$ & Remark & $\begin{array}{l}\text { Chronbach } \\
\text { alpha }\end{array}$ \\
\hline Product/ service strategy & 3.55 & 0.95 & 10.03 & $0.000^{*}$ & Agree & 0.804 \\
\hline Pricing strategy & 3.19 & 1.05 & 3.13 & $0.001^{*}$ & Agree & 0.811 \\
\hline $\begin{array}{l}\text { Process strategy /Service } \\
\text { Delivery }\end{array}$ & 3.59 & 0.99 & 10.32 & $0.000^{*}$ & Agree & 0.780 \\
\hline Place strategy & 3.46 & 0.95 & 8.39 & $0.000^{*}$ & Agree & 0.760 \\
\hline Personnel (people) strategy & 3.55 & 0.96 & 9.92 & $0.000^{*}$ & Agree & 0.792 \\
\hline Promotional strategy & 3.52 & 0.96 & 9.38 & $0.000^{*}$ & Agree & 0.793 \\
\hline Physical evidence strategy & 3.59 & 0.94 & 10.87 & $0.000^{*}$ & Agree & 0.801 \\
\hline $\begin{array}{l}\text { Overall knowledge of } \\
\text { marketing strategy }\end{array}$ & 3.49 & 0.97 & 8.75 & $0.000^{*}$ & Agree & \\
\hline
\end{tabular}

*Statistically significant at 5\% alpha level (0.05)

Source: Authors calculation 
The finding revealed that the customers of the various mobile telecommunication companies agreed that they were aware of all the marketing strategies of their service provides since the probabilities values are less than the significant value of $0.05(\mathrm{p}<0.05)$. The dimension of the $7 \mathrm{P}$ marketing strategies implemented by the mobile telecommunication companies which the customers were aware of included; product/ service strategy (Mean=3.55, Stdev=0.95), pricing strategy (Mean=3.19, Stdev=1.05), process strategy /Service delivery (Mean=3.59, Stdev=0.99), place strategy (Mean=3.46, Stdev=0.95), personnel (people) strategy (Mean=3.55, Stdev=0.96), promotional strategy (Mean=3.52, Stdev=0.96), and physical evidence strategy(Mean=3.59, $\mathrm{Stdev}=0.94)$. The Cronbach alpha value indicates the reliability of the findings. The value of 0.70 is the ideal value of reliability (Hair et al. 2007). This reliability of customer awareness of all the dimensions of the 7P marketing strategies is within the acceptability limit.

The respondents therefore were aware of the marketing strategies implemented by the respective mobile telecommunication companies (Mean=3.49, Stdev=0.97, $\mathrm{z}=8.75, \mathrm{p}=0.000$ ). The implications of these findings for the various marketing mix elements are as follows:

- The Product/service strategy: The respondents agreed that they were aware of the product/service strategies used by their network (Mean=3.55, Stdev=0.95, $\mathrm{z}=10.03, \mathrm{p}=0.000$ ). furthermore, it was revealed that the customers are satisfied with some of the products and services of their telecommunication companies; the telecommunication companies provide wide variety of products and service that suit their needs; the telecommunication companies provide more innovative products,; the products and services do attract my purchases; and that they do patronize more of the products and services of the telecommunication companies. Therefore, based on the results, it does appear that generally in terms of awareness of product and service delivery, the various mobile telecommunications companies in Ghana have made a good impression in the minds of customers in the market.

- The Place strategy: The respondents again agreed that they were aware of the place marketing strategies adopted by their network (Mean $=3.46, \mathrm{Stdev}=0.95, \mathrm{z}=8.39, \mathrm{p}=0.000^{*}$ ). This means that the customers agreed that their telecommunication companies have brought their product/services closer to them. The respondents also indicated that: it is very easy and convenient to access mobile telecommunication services; it is very easy to locate the offices of the telecommunication companies; purchases of the product meet their service needs from the telecommunication mobile shops; the online/virtual system through company websites, social media platforms among others meets and resolve the telecommunication needs of customers; the physical offices also serve as a place for customers to purchase their telecom products and resolve their service problems due to its nearness. Distribution is about getting the products to the customer (McCarthy, 1999; Szopa and Pękała, 2012). Therefore when customers are able to get the product or service when needed, it contributes to the visibility and competitiveness of the companies.

- The pricing strategy: The respondents agreed that they were aware of the pricing strategies adopted by their network (Mean=3.19, Stdev=1.05, $\mathrm{z}=3.13, \mathrm{p}=0.001$ ). This implies that the pricing strategies generate attention and tends to attract new customers; the pricing strategy help maintain loyal customers; the telecommunication companies offer flexible ways of payment; customers are generally very satisfied with the billing system of their mobile network operator; and that the pricing systems of their telecommunication companies are better than others. Pricing strategies in the form of discounts influences the customer in the buying-process at the point of purchase. The reduction in price has the effect of catching the attention of the customers (Festa, Cuomo, Metallo and Festa, 2016). Furthermore, the findings is confirmed by the study by Inman, McAlister and Hoyer (1998) that found that customers are more likely to purchase a product with a lowered price in developing countries.

- The Promotional strategy: The respondents agreed that they were aware of the promotional marketing strategies adopted by their network provider (Mean=3.52, Stdev=0.96, $z=9.38$, $\mathrm{p}=0.000$ ). This implies that the customers are exposed to the various promotional activities that 
are offered by these telecommunication companies and the various promotional activities are satisfactory. Some of the customers explained that the promotional activities done by the telecommunication companies are helpful; the promotional activities induce customers to purchase more of the product/services; and that the telecommunication companies' help in developing the communities they operate in. It can therefore be said that the promotional strategies provide positive information on the service, perceived or real and can be defined as a feature of the product (McCarthy, 1999) to influence customer purchases.

- The People strategy: The respondents again agreed that they were aware of the personnel marketing strategies adopted by their network (Mean=3.55, Stdev=0.96, $z=9.92, p=0.000$ ). The respondents indicated that, the employees of the telecommunication companies are patient in responding to their complaints; they are satisfied with the professionalism of employees of their network provider/providers; they get educated on the offers and services by the service personnel; the telecommunication companies demonstrate adequate knowledge of the products and services; and that they are positively influenced by the conduct of the employees of their preferred network provider/ providers. In service-oriented companies such as the mobile telecommunication industry, the importance of employees and especially the contact between the employees and customers is key in the delivery of high-quality service as well as contributing to overall customer satisfaction (Blumberg, Cooper, \& Schindler, 2005; Chaudhuri and Ligas, 2009).

- The Process /Service delivery strategy: The respondents agreed that they were aware of the process/service delivery marketing strategies adopted by their network provider (Mean $=3.59$, Stdev $=0.99, z=10.32, p=0.000$ ). The respondents explained that the process of loading credit vouchers are simple and quick, the process of renewing their internet bundle are very satisfying; the process of subscribing to the products/services are easy; they are satisfied with the overall processes of their network provider/providers; and that the telecommunication companies are quick in resolving their complaints. This finding affirms the assertion that the process or mode of service delivery could affect the initial decisions by customers to buy a product or service and may further influence the level of customer satisfaction (Festa, Cuomo, Metallo and Festa, 2016).

- The Physical evidence strategy: The customers also agreed that they were aware of the physical evidence aspect of the marketing strategies adopted by their network service providers (Mean=3.59, Stdev=0.94, $\mathrm{z}=10.87, \mathrm{p}=0.000$ ). The respondents agreed to the following with respect to the telecommunication companies; the colors use are very attractive, the arrangements in the offices are neatly done, the environment in which they are located is neat; the appearance of the offices are very attractive and the building designs are done with customers in mind. This finding confirms the assertion by services marketing researchers (Lovelock, 2001; Palmer, 2001) that the relevance of physical evidence in service based companies is to send a consistent message and retain a coherent image about the organization. It is to focus on the significant role of providing tangibles as a significant component of the company service offer (Palmer, 2001).

To demonstrate which mobile network customers had more knowledge of the marketing strategies, a non-parametric Kruskal Wallis $\mathrm{H}$ test was done to compare the responses given by the customers. The findings are presented in Table 3 below. 
TABLE 3

CUSTOMER AWARENESS OF THE 7P MARKETING STRATEGIES COMPARED

\begin{tabular}{|l|l|l|l|}
\hline Marketing mix & $\mathrm{N}$ & $\mathrm{H}$ & $\mathrm{p}$-value \\
\hline Pricing strategy & 300 & 8.702 & 0.122 \\
\hline Product/Service strategy & 300 & 7.379 & 0.194 \\
\hline Process Strategy & 300 & 1.590 & 0.902 \\
\hline Place strategy & 300 & 8.429 & 0.134 \\
\hline Personnel strategy & 300 & 12.002 & $0.035^{*}$ \\
\hline Promotional strategy & 300 & 24.260 & $0.000^{*}$ \\
\hline Physical evidence strategy & 300 & 15.333 & $0.009^{*}$ \\
\hline
\end{tabular}

*Statistically significant difference at .05 Alpha level

Source: Authors calculation

The outcome of the comparison reveals that significant differences exist in the level of customer awareness of some marketing strategies of the mobile telecommunication companies $(p<0.05)$. These include personnel strategy $\left(\mathrm{p}=0.035^{*}\right)$, the promotional strategy $(\mathrm{p}=0.000)$ and the physical evidence strategy $(\mathrm{p}=0.009)$ which were all significant. However, there was no statistically significant difference in customers' response about their knowledge of the marketing strategies relating to pricing, product/service, process, and place $(\mathrm{p}>0.05)$ for all the customers sampled. The implication is that the customers had about the same knowledge of these marketing strategies. The reason is that there are not much differences in the marketing mix approach that are used by the various mobile telecommunication companies.

\section{Customer Purchase Decision of Products and Services in the Mobile Telecommunication Industry}

The second objective of the study examines customer purchase decision of products and services in the mobile telecommunication industry in Ghana. To determine the intentions of the customers of the various mobile networks to patronize the service of the network, analysis was done using the Kruskal Wallis $\mathrm{H}$ test. The findings revealed that there is no significant difference in the intentions of respondents to patronize their networks $(\mathrm{p}>0.05)$. The results are shown in table 4 .

INTENTION OF CUSTOMERS TO PATRONIZE THE NETWORK COMPARED

\begin{tabular}{|l|l|l|l|}
\hline & $\mathrm{N}$ & $\mathrm{H}$ & $\mathrm{p}$-value \\
\hline Intention to purchase the service of the network & 300 & 7.360 & .195 \\
\hline
\end{tabular}

Source: Authors calculation

Furthermore, to throw more light on the above findings, customer intention to remain loyal to the services of their various networks was measured on a five-point Scale. Mean and standard deviation were used to present the findings. If the overall mean value significantly greater than 3.0 (Test value) then the customers agreed that they would continue to purchase services their networks. One-sample z-test was performed at $5 \%$ alpha to determines whether or not the overall mean value is greater than 3.0 using the hypothesis (Ho: $\mu \leq 3.0 ; \mathrm{H} 1: \mu>3.0$ ). The results found were summarized in table 5 below. 
TABLE 5

INTENTION OF CUSTOMERS TO PATRONIZE THE SERVICE OF THEIR NETWORK

\begin{tabular}{|l|l|l|l|}
\hline Cronbach's alpha=0.776 & $\mathrm{N}$ & Mean & Stdev \\
\hline Irrespective of the validity of the offer i.e. how long the offer will last & 300 & 3.54 & 0.86 \\
\hline The informative nature of the marketing strategy & 300 & 3.53 & 0.82 \\
\hline $\begin{array}{l}\text { The level of response to complaints by the personnel's of the } \\
\text { telecommunication companies }\end{array}$ & 300 & 3.50 & 0.85 \\
\hline The conducive environment and location of the telecommunication companies & 300 & 3.49 & 0.84 \\
\hline The various product and services used by the telecommunication companies & 300 & 3.46 & 0.81 \\
\hline Type of product/service being promoted & 300 & 3.44 & 0.86 \\
\hline the billing system of our mobile network operator & 300 & 3.43 & 0.84 \\
\hline $\begin{array}{l}\text { Irrespective of the timing of sales promotions e.g. during holidays, weekends } \\
\text { or festive seasons influence me. }\end{array}$ & 300 & 3.31 & 0.87 \\
\hline Overall customer intention to patronize mobile services & 300 & 3.46 & 0.96 \\
\hline
\end{tabular}

*statistically significant at $5 \%$ alpha

Source: Authors calculation

The output indicates that the customers overall demonstrated that they would continue to purchase the products and services of their mobile service providers (Mean=3.46, Stdev=0.96, $\mathrm{z}=8.30, \mathrm{p}=0.000 *$ ). Therefore customers would patronize services of their network provider $(\mathrm{p}<0.05)$ though their intention is not absolute (100\%). This means that the respondents assertions that they would patronize the service of their networks irrespective of the validity of the offer i.e. how long the offer will last (Mean=3.54, Stdev=0.84), the informative nature of the marketing strategy (Mean=3.53, Stdev=0.82), provided they are influenced by marketing strategies of the Telecom companies (Mean=3.52, Stdev=1.87), irrespective of the level of response to complaints by the personnel's of the telecommunication companies (Mean=3.50, Stdev $=0.85$ ), the conducive environment and location of the telecommunication companies (Mean=3.49, Stdev $=0.84$ ), the various product and services used by the telecommunication companies (Mean=3.46, Stdev=0.81), the type of product/service being promoted (Mean=3.44, Stdev=0.86), the billing system of our mobile network operator (Mean=3.43, Stdev=0.84), and that they would patronize the services irrespective of the timing of sales promotions e.g. during holidays, weekends or festive seasons influence me $($ Mean=3.31, Stdev=0.87).

\section{The Effect of Customer Awareness of Marketing Strategies (Marketing Mix) on Customers' Purchase Decision in the Mobile Telecommunication Industry}

The third objective of the study was to evaluate the effect of customer awareness of marketing strategies on customer purchase decision in the mobile telecommunication industry. For this objective, correlation and regression analysis were performed. The result of the inter-item correlation matrix is shown Table 6 below.

TABLE 6

\section{CORRELATIONS BETWEEN VARIABLES}

\begin{tabular}{|l|l|l|}
\hline \multicolumn{2}{|c|}{} & Customer purchase decision \\
\hline \multirow{3}{*}{ Pricing strategy. } & Pearson Correlation & $.146^{*}$ \\
\cline { 2 - 3 } & Sig. (2-tailed) & .011 \\
\cline { 2 - 3 } & $\mathrm{N}$ & 300 \\
\hline \multirow{3}{*}{ Product/Service } & Pearson Correlation & $.120^{*}$ \\
\cline { 2 - 3 } & Sig. (2-tailed) & .038 \\
\cline { 2 - 3 } & $\mathrm{N}$ & 300 \\
\hline
\end{tabular}




\begin{tabular}{|l|l|l|}
\hline Process strategy & Pearson Correlation & $.153^{* *}$ \\
\cline { 2 - 3 } & Sig. (2-tailed) & .008 \\
\cline { 2 - 3 } & $\mathrm{N}$ & 300 \\
\hline \multirow{5}{*}{ Place strategy } & Pearson Correlation & .042 \\
\cline { 2 - 3 } & Sig. (2-tailed) & .469 \\
\cline { 2 - 3 } & $\mathrm{N}$ & 300 \\
\hline Personnel strategy & Pearson Correlation & .079 \\
\cline { 2 - 3 } & Sig. (2-tailed) & .170 \\
\cline { 2 - 3 } & $\mathrm{N}$ & 300 \\
\hline Promotional strategy & Pearson Correlation & $.129^{*}$ \\
\cline { 2 - 3 } & Sig. (2-tailed) & .025 \\
\cline { 2 - 3 } & $\mathrm{N}$ & 300 \\
\hline Physical evidence strategy & Pearson Correlation & .079 \\
\cline { 2 - 3 } & Sig. (2-tailed) & .171 \\
\cline { 2 - 3 } & $\mathrm{N}$ & 300 \\
\hline
\end{tabular}

**. Correlation is significant at the 0.01 level (2-tailed).

*. Correlation is significant at the 0.05 level (2-tailed).

Source: Authors calculation

The output revealed that customer awareness of some marketing strategies had significant positive correlation with customer purchase decision $((\mathrm{p}<0.01)$. Customer awareness of the pricing strategy $(\mathrm{r}=.146$, $\mathrm{p}=.011)$, product/Service strategy $(\mathrm{r}=.120, \mathrm{p}=.038)$, process strategy $(\mathrm{r}=.153, \mathrm{p}=.008)$, and promotional strategies $(\mathrm{r}=.129, \mathrm{p}=.025)$ all have significant positive correlation on customer intention to patronize the services of their mobile network. The finding corroborates the study of Obasan and Soyebo (2012) which showed that promotion has a key effect on marketing management with a correlation value of 0.869 which implies that promotion is a good marketing tool for survival, sustenance and expansion of business Telecommunication Industry. The current study also found positive correlation between customer awareness of marketing strategies and customer purchase decision. The means the marketing strategy of the mobile telecommunication companies is effective in creating customer awareness of the services and products of the companies but not effective in influencing customer purchase decisions. Peng, Yow and Wang (2006) also observed sales promotion provides a suitable link by providing consumers with samples of the products for them for them to test them in small quantities as well as provide consumers with the most needed information concerning the product. The mobile companies therefore have only succeeded through promotional strategies to introduce the services and products to the customer but not influencing the purchasing decision of the customers through the other elements of the marketing mix.

The correlation results in table 6 implies that as customers become more aware of these marketing strategies, there is higher probability that it would affect their decision to patronize the services of their mobile telecommunication service providers. The above is just establishing a relationship. However, the study went further to determine if the marketing strategies can predict the decision to patronize the services of their mobile telecommunication service providers. This is because the marketing strategies are likely to be the main predictors of customer purchase decision of the services of the mobile networks. Table 7 shows the outcome of the regression analysis. 


\section{TABLE 7}

\section{REGRESSION ANALYSIS}

\begin{tabular}{|c|c|c|c|c|c|}
\hline \multirow[t]{2}{*}{ Model } & \multicolumn{2}{|c|}{$\begin{array}{l}\text { Unstandardized } \\
\text { Coefficients }\end{array}$} & \multirow{2}{*}{$\begin{array}{l}\text { Standardized } \\
\text { Coefficients } \\
\text { Beta }\end{array}$} & \multirow[t]{2}{*}{ t-stat } & \multirow[t]{2}{*}{ Sig. } \\
\hline & $\mathrm{B}$ & Std. Error & & & \\
\hline (Constant) & 2.566 & .274 & & 9.365 & $.000 *$ \\
\hline Pricing strategy & .074 & .055 & .087 & 1.346 & .179 \\
\hline Product/Service & .034 & .059 & .039 & .577 & .565 \\
\hline Process strategy. & .075 & .051 & .094 & 1.473 & .142 \\
\hline Place strategy. & .020 & .054 & .024 & .374 & .709 \\
\hline Personnel strategy & .002 & .065 & .002 & .032 & .974 \\
\hline Promotional strategy & .070 & .067 & .074 & 1.044 & .297 \\
\hline Physical evidence strategy & .003 & .058 & .003 & .051 & .959 \\
\hline
\end{tabular}

R-square $=4.0 \%$, F-distribution $=1.738$, Prob. $(\mathrm{F})=0.10$

*statistically significant at $5 \%$ alpha

Source: Authors calculation

The outcome revealed that, overall, none of the marketing strategies had significant influence on customer purchase decision $(\mathrm{F}=1.738, \mathrm{p}=0.10)$. This means that customer awareness of marketing strategies of the companies though correlated positively with customer decision to patronize the service of the mobile telecommunication companies, the knowledge of customers about the marketing strategies is not the only factor that determines the intention of the customer to patronize the services of mobile network companies. It was found that some other factors also contribute to customer purchase decision other than their knowledge of the marketing strategies of the mobile telecommunication companies. The other factors may include (service quality delivery, customer satisfaction of service delivery, trust, corporate social responsibility, customer relationship management practices among others). As indicated by McCarthy (1999), the after-sales support such as customer service and warranty which is an essential requirement of customer relationship management also influences customer purchase decision. It is important to note that, though there is a relationship between marketing mix strategy and decision to patronize the services of their mobile telecommunication companies, it would be erroneous to conclude that the marketing mix strategy could predict the decision to patronize the products and services of mobile telecommunication companies.

\section{CONCLUSIONS AND RECOMMENDATION}

Based on its findings the study concludes that customers of the various mobile telecommunication companies in Ghana can be said to be knowledgeable of the marketing strategies used by their network providers. Customers of companies that engage in more advertisement of their products have more knowledge of the marketing strategies than customers' of the other networks. Customers have high intention to purchase the services of their network. The purchase decision of customers is the same across networks. As the customers' level of awareness of the marketing strategies increased, their purchase decision also increased but customers' knowledge and awareness of the marketing strategy cannot be the sole predictor of purchase decision. Consequently, it is recommended that mobile telecommunication companies continue to create customers awareness of the services using the 7P marketing mix. This may have some level of influence on customer purchase decisions. However, managers should not lose sight of other variables such as service quality delivery, customer satisfaction of service delivery, trust, corporate social responsibility, customer relationship management practices among others that are known to influence customer purchase intentions. It is essential for managers of telecommunication companies to improve their marketing strategies to create and reinforce customer awareness. This is particularly so for those companies with low awareness levels. It is further recommended that companies in the mobile telecommunication industry 
increase the purchase decisions of the customer through promotional and pricing strategies in particular whiles strengthening other factors such as service quality, trust and corporate social responsibility. The use of promotional strategies should not only focus on price and product benefits, but also on the other elements of the marketing mix. Knowledge of customers about the marketing strategies of companies alone did not significantly affect their purchase decision rather other factors that elicited emotional and cognitive appeal shaped customer perception and affected their decision to want to patronize products and services from the telecommunication companies.

\section{REFERENCES}

Adcock, D., Halborg, A., \& Ross, G. (2001). Marketing Principles and Practice (4 ${ }^{\text {th }}$ ed.). Pearsons Education, Harlow, England.

Ala'Eddin, M.K., Abdullah, A.A., Dalia, A.Q., \& Najla, K. (2013). The Impact of Marketing Mix Strategy on Hospitals Performance Measured by Patient Satisfaction: An Empirical Investigation on Jeddah Private Sector Hospital Senior Managers Perspective. International Journal of Marketing Studies, 5(6), 210-227.

Asamoah, E.S. (2014). Customer based brand equity (CBBE) and the competitive performance of SMEs in Ghana. Journal of Small Business and Enterprise Development, 21(1), 117-131.

Asamoah, E.S. (2021). Monopolistic Market Structure and the Firms' Competitiveness in the Global Fast Food Industry: Implications for Cost, Profit and Revenue. Journal of Management and Economics, 1, 20-32.

Barlon, K. (2006). The concept of the marketing mix. Marketing Management, 1, 2-7.

Beckett, A. (2000). An exposition of consumer behavior in the financial services industry. International Journal of Bank Marketing, 18(1), 15-26.

Bilal, Z.O., \& Al Mqbali, N.S. (2015). Challenges and constrains faced by small and medium enterprises (SMEs) in Al Batinah governorate of Oman. World Journal of Entrepreneurship, Management and Sustainable Development, 11, 120-130.

Blackwel, R.D., Minniard, P.W., \& Engel, J.L. (2001). Consumer behaviour (5 ${ }^{\text {th }}$ ed.). The Dryden Press.

Blackwell, R.D., Miniard, P.W., \& Engel, J.F. (2006). Consumer behavior (10 ${ }^{\text {th }}$ ed.). Boston: Thomson South-Western.

Blumberg, B., Cooper, D.R., \& Schindler, P.S. (2005). Business research methods ( $2^{\text {nd }}$ ed.). Berkshire: McGraw-Hill Education.

Booms, B.H., \& Bitner, M.J. (1981). Marketing strategies and organizational structures for service firm. In J.H. Donnelly \& W.R. George (Eds.), Marketing of Services (pp. 47-52). Chicago: American Marketing Association.

Brassington, F., \& Pettitt, S. (2001). Principles of Marketing (3rd ed.). Pearson Education, Prentice Hall.

Chaniotakis, I.E., Lymperopoulos, C., \& Soureli, M (2010). Consumers' intentions of buying own-label premium food products. Journal of Product and Brand Management, 19(5), 327-334.

Chaudhuri, A., \& Ligas, M. (2009). Consequences of Value in Retail Markets. Journal of Retailing, 85(3), 406-419.

Clancy, K.J., \& Kriegafsd, P.C. (2000). Counterintuitive Marketing. The Free Press.

Festa, G., Cuomo, M.T., Metallo, G., \& Festa, A. (2016). The (r) evolution of wine marketing mix: From the 4Ps to the 4Es. Journal of Business Research, 69, 1550-1555.

Grönroos, C. (2000). Service Management and Marketing. A Customer Relationship Management Approach. Chichester: Wiley \& Sons.

Inman, J.J., McAlister, L., \& Hoyer, W.D. (1990). Promotion Signal: Proxy for a price cut? Journal of Consumer Research, 17(1), 74-81.

Jones, R. (2003). Making health information accessible to patients. Aslib Proceedings, 55(5/6), 334-338.

Kotler, P. (2010). Marketing Management Millennium Edition (10 ${ }^{\text {th }}$ ed.). Boston: Prentice-Hall, Inc.

Kotler, P. (2001). Marketing Management (10 ${ }^{\text {th }}$ ed.). Tsinghua University Press.

Kotler, P., \& Keller, K.L. (2009). Marketing Management (13 ${ }^{\text {th }}$ ed.). Pearson Prentice Hall. 
Latif, A., \& Abideen, Z.U. (2011). Effects of television advertising on children: A Pakistani perspective. European Journal of Economics, Finance and Administrative Sciences, 30(4), 38-49.

Lavie, D. (2006). Capability reconfiguration: An analysis of incumbent responses to technology change. Academy of Management Executive, 31(1), 153-174.

Lovelock, C. (2001). Services Marketing People, Technology, Strategy (4th ed.). Prentice Hall.

McCarthy, E.J. (1999). Basic marketing: A managerial approach. Homewood, IL: Irwin.

Obasan, K.A., \& Soyebo, Y.A. (2012). Assessing the effectiveness of promotion as a marketing management tool in the Nigerian telecommunication industry. Journal of Emerging Trends in Economics and Management Sciences, 3(1), 1-6.

Palmer, A. (2001). Principles of Services Marketing (3rd ed.). UK: McGraw-Hill Publishing Company.

Peng, L.Y., \& Wang, Q. (2006). Impact of relationship marketing tactics on switchers and stayers in a competitive service Industry. Journal of Marketing Management, 22, 25-59.

Sashi, C.M. (2012). Customer engagement, buyer-seller relationships, and social media. Management Decision, 50, 253-272.

Saunders, M., Lewis, P., \& Thornhill, A. (2009). Research Methods for Business ( ${ }^{\text {rd }}$ ed.). Prentice Hall Pearson Education.

Schiffman, G.L., \& Kanuk, L. (2007). Consumer Behaviour ( $9^{\text {th }}$ ed.). Prentice Hall.

Singh, M. (2012). Marketing mix of 4P's for competitive advantage. Journal of Business and Management, 3(6), 40-45.

Subramanyam, D., \& Venkateswarlu, M. (2012). Factors Influencing Buyer Behaviour of Mobile Phone Buyers in Kadapa District. Indian Journal of Research, 1(11), 3-5.

Szopa, P., \& Pękała, W. (2012). Distribution channels and their roles in the enterprise. Polish Journal of Management Studies, 6, 143-150.

Wang, J-L., Wang, H-Z., Gaskin, J., \& Wang, L-H. (2015). The role of stress and motivation in problematic smartphone use among college students. Computers in Human Behavior, 53, 181188.

Zeithaml, V., \& Bitner, M. (2000). Services Marketing: Integrating Customer Focus Across the Firm (2 ${ }^{\text {nd }}$ ed.). Irwin McGraw-Hill. 